(second edition) of Jordan's "Cours d'Analyse de l'école Polytechnique," which is devoted to the integral calculus, fully analyses its contents, and pronounces it to be " a substantially new contribution to mathematical literature." "From beginning to end the reader feels that he is being guided by a master-hand." -Prof. E. Hastings Moore writes on a theorem concerning p-rowed characteristics with denominator 2. (of Prym's "Untersuchungen iber die Riemann'sche Thetaformel und die Riemann'sche Charakteristikentheorie," I882). - A note on the Transitive Substitution Groups of degree 12, by Dr. G. A. Miller, mentions that Camille Jordan in the Comptes rendus (vol. lxxv. p. 1757) states that there are three primitive groups of degree 12, excluding the groups which contain the alternating group. Dr. Millex has found four multiply transitive primitive groups of this degree, excluding the two groups containing the alternating group The proof is given in the present note.

\section{SOCIETIES AND ACADEMIES.}

PARIS.

Academy of Sciences, September 30.-M. A. Cornu in the chair.- The Perpetual Secretary read a letter from M. J. B. Pasteur, announcing the death of his father, Louis Pasteur, who ried at Villeneuve-l'Étang (Garches), on September 28, I895. M. A. Cornu then expressed the deep feeling of loss in the Academy, and recalled the greatness of the work accomplished by Pasteur. As a mark of respect and sorrow the Academy adjourned after receiving the correspondence.-Remarks on the subject of Lord Salisbury's discourse " on the real limits of our science," by M. Emile Blanchard. The author recalls his work in contradiction to the theory of the origin of species advanced by Darwin, and maintains that no single instance has ever been brought forward in answer to his challenge which can be held to verify the assumption that one species may be produced from another by any form of selection. - On glycosuria following ablation of the pancreas, by M. R. Lépine, The sugar contents of the urine have been determined, and glycosuria traced during the first thirty hours, operating on dogs without the use of anæsthetics or morphine.-A study of the mechanical theory of heat, by M. Ch. Brun, has been printed in the correspondence. - The evaporation of liquids and the great capillary theories, by M. G. Van der Mensbrugghe. Most liquids evaporate spontaneously in the air. The consequences follow: (I) The liquid layer whence particles are continually being detached to form vapour cannot have the same density as the liquid in the interior of the mass, otherwise there would be an abrupt passage from the liquid state to vapour ; it must, therefore, be admitted that the density of the superficial layer decreases towards the exterior. All capillary theories, supposing liquids incompressible (Laplace), or of the same density throughout (Gauss), are therefore inadequate. (2) When the mass considered is very small (bubbles, liquid films), evaporation causes loss of a perceptible fraction of the total weight. Hence capillary theories regarding a liquid mass as having an invariable volume (Poisson) must be condemned. (3) The constant renewal of the free surface of the superficial layer proves, without possible doubt, that this layer is not in equilibrium. What confidence can then be placed in the theories of Laplace, Gauss, and Poisson, and the works of contemporary analysts (Neumann, Mathieu, Van der Waals, Resal, and Poincaré), who formally suppose a liquid mass in equilibrium? After calling attention to the defects of former theories, the author quotes his own theory, derived from a consideration of molecular forces, as giving a sufficient explanation of these consequences. - On a new nitrogenous manure, calcium cyanate, by $\mathrm{M}$. Camille Faure. It is asserted that calcium cyanate can be produced in large quantity in the electric furnace by heating lime and charcoal intensely in an atmosphere of nitrogen, and oxidising the product by air. The cyanate contains a greater proportion of assimilable nitrogen than nitrate, and can be used as a manure. - Syntheses by means of cyanacetic esters, by M. T. Klobb - Constitution of acids produced in the oxidation of inactive campholenic acids, by M. A. Béhal. The acid $\mathrm{C}_{6} \mathrm{H}_{10} \mathrm{O}_{4}$ is dissymmetric dimethylsuccinic acid; the acid $\mathrm{C}_{7} \mathrm{H}_{12} \mathrm{O}_{4}$ is one of the two dimethylglutaric acids having the two methyls attached to the same carbon atom, probably $\mathrm{CO}_{2} \mathrm{H} \cdot \mathrm{C}\left(\mathrm{CH}_{3}\right)_{2} \cdot \mathrm{CH}_{2} \cdot \mathrm{CH}_{2} \cdot \mathrm{CO}_{2} \mathrm{H}$. The author claims priority for his work against that of Tiemann.-On the effects of the synodic and anomalistic revolutions of the moon on he distribution of pressures in spring, by M. A. Poincaré.-On a double night ascension (balloon) made on September 4, by MM. G. Hermite and Besançon. Two balloons made voyages from Paris in opposite directions, starting at the same time. The currents observed and used are described, together with details of the voyages.

BOOKS, PAMPHLETS, and SERIALS RECEIVED.

Books.-A Hand-book to the Birds of Great Britain : Dr. R. B. Sharpe, vol. 2 (Allen).-Climbing in the British Isles: W. P. H. Smith and H.C. Hart, II. Wales and Ireland (Longmans). - Practical Proofs of Chemical I.aws: V. Cornish (Longmans).-An Introduction to the Study of Seaweeds: G. Murray (Macmillan).-Catalogue of the Library of the Royal Geographical Society : Dr. H. R. Mill (Murray).-Dynamics: Prof. P. G. Tait (Black). - Farm Foods, or the Rational Feeding of Farm Animals: Prof. E. v. Wolff, translated by H. H. Cousins (Gurney).-The Gold Mines of the Rand: F.'H. Hatch and J. A. Chalmers (Macmillan). - The Fauna of British India, including Ceylon and Burma; Birds, Vol. 3 : W. T. Blanford (Taylor and Francis).--Popular History of Animals for Young People : H. Scherren (Cassell). - Moral Pathology : Dr. A. E. Giles (Sonnenschein). The Splash of a Drop: Prof. A. M. Worthington (S.P.C. K.). - Simple Methods for detecting Food Adulteration: J. A. Bower (S.P.C.K.). Biology Notes, Vol. I (Chelmsford) -Einführung in das Studium der Bakteriologie : Dr. C. Günther, Vierte Auflage (Leipzig, Thieme). - Natural History of Selborne: Gilbert White, 2 Vols. illustrated (Macmillan). - The Scientific Foundations of Analytical Chemistry: Prof. W. Ostwald, trans-
lated by Dr. G. M'Gowan (Macmillan). - The Structure of Man : Dr. R. lated by Dr. G. M'Gowan (Macmillan). - The Structure of Man : Dr. R.
Wiedersheim, translated by H. and M. Bernard (Macmillan).- Weather Wiedersheim, translated by $\mathrm{H}$. and M. Bernard (Macmillan).-Weather
and Disease: A. B. MacDowall (Graphotone Company).-Old Farm and Disease: A. B. MacDowall (Graphotone
Fairies: H. C. McCook (Hodder and Stoughton).

Fairies: H. C. McCook (Hodder and Stoughton).
PAMPHLETS.-Les Limites Actuelles de Notre Science: Marquis de PAMPHLETS.-Les Limites Actuelles de Notre Science: Marquis de
Salisbury, translated by W. de Fonvielle (Paris, Gauthier-Villars).-ReacSalisbury, translated by W. de Fonvielle (Paris, Gauthier-Villars).- - Reac-
tion : : K. Pearson (Reeves). - Guide to the Collections of Rocks and Fossils tion : : K. Pearson (Reeves). - Guide to the Collections of Rocks and Fossils belonging to the Geological Survey of Ireland: A. McHenry and W. W.
Watts (Dublin, Thom).-A Supplement to a Revised Account of the ExWatts (Dublin, Thom).-A Supplement to a Revised Account of the Ex-
periments made with the Bashforth Chronograph : F. Bashforth (Cambridge University Press). - Ein Brauner. Tschimpanse im Dresdner Zoologischen Garten: A. B. Meyer (Berlin, Friedländer).

SERIALS.- Journal of the Royal Agricultural Society of England, Vol. vi. Part 3 (Murray). - Natural History of Plants: Kerner and Oliver, Part 16 (Blackie). - Mind, October (Williams and Norgate). - Transactions of the Perthshire Society of Natural Science, Vol. 2, Part 2 (Perth). - Geological Magazine, October (Dulau).-Morphologisches Jahrbuch, 23 Band, I Heft (Leipzig,Engelmann). - Bulletin de la Société Impériale des Naturalistes de Moscou, 1895, No. 2 (Moscou).-Geographical Magazine, October (Stanford).- -Story of the Heavens : Sir R. S. Bail, Part I (Cassell).-Ethnologisches Notizblatt, Heft 2 (Berlin, Haack).- Bulletin de l'Académie Royale des Sciences de Belgique, 65 Anné, No. 8 (Bruxelles).-American Naturalist, October (Philadelphia).-Annals of Scottish Natural History, October (Edinburigh, Douglas). - Memoirs and Proceedings of the Manchester Literary and Philosophical Society, Vol. 9, No. 6 Manchester).Science Progress, October (Scientific Press).--Mlustrated Archæoologist, and
Reliquary, October (Bemrose). - Travaux de la Société des Naturalistes de St. Pétersbourg, Vol. xxiii. (St. Pétersbourg).

\section{CONTENTS.}

PAGE

Liebig. By W. A. T. 565

The Selection of Health Resorts . . . . . 566 Our Book Shelf :-

Henry : "Abrégé de la Théorie des Fonctions Elliptiques."-H. F. Baker ........ 567

\section{Letters to the Editor:-}

Clausius' Virial Theorem.-Prof. A. Gray; S. H. Burbury, F.R.S. ; Robert E. Baynes . . . . 568 Hutton's "Theory of the Earth."-Frank D. Adams 569 Abnormal Atlantic Waves.-James Yate Johnson. 569 Leaf-absorption.-G. Paul; W. Botting Hemsley, F.R.S.

Tertiary Fossil Ants in the Iste of Wight. $-\dot{P}$. $\dot{B}^{\circ}$ Brodie

The Normal School at Paris. 'By $\dot{R}$. A. Gregory 570 The "Gemmi" Disaster. (Illustrated.) By Maria M.

Ogilvie, D.Sc.

The Late Professor Hoppe-Seyler. By Dr. Arthur

Gamgee, F.R.S. . . . . . . . . . 575

The Funeral of Pasteur. . . . . . . . 576

Notes . . . . . . . . 579

Our Astronomical Column:-

Measurement of Planetary Diameters . . . . . 579

The Craters on the Moon . . . . . . . 579

Suggestion for Astronomical Research . . . . . . 579

Anthropology at the British Association . . . . 580

Mechanics at the British Association ..... . $5^{81}$

Botany at the British Association ... . . . . 584

Science in the Magazines . . . . . . . . . 586

University and Educational Intelligence . . . . 587

Scientific Serials . . . . . . . . . 587

Societies and Academies ... . . . . . . . 588

Books, Pamphlets, and Serials Received . . . 598

NO. I 354, VOL. 52] 